\title{
Occurrence of Spontaneous Tetraploid Nucellar Mango Plants
}

\author{
Víctor Galán Saúco ${ }^{1}$, María José Grajal Martín, and \\ Domingo Fernández Galván \\ Dept. Tropical Fruit, Instituto Canario de Investigaciones Agrarias. Apdo. \\ 60. La Laguna 38200 Tenerife (Canary Islands) Spain
}

\author{
Águeda Coello Torres \\ Cabildo Insular de Tenerife. Plaza de España s/n. Santa Cruz de Tenerife \\ 38071 Spain
}

\section{José Juárez and Luis Navarro \\ Dept. Plant Protection and Biotechnology, Instituto Valenciano de Investigaciones Agrarias. Apdo. Oficial. Moncada 46113 Valencia, Spain}

Additional index words. flow cytometry, polyploidy, Mangifera indica, Canary Islands

\begin{abstract}
A putative polyploid seedling tree appeared among the polyembryonic mango (Mangifera indica L.) 'Gomera-1', widely used as a rootstock in the Canary Islands. Initially detected because of its wider and more coriaceous leaves, further studies showed that fruit from this seedling are considerably larger than normal, although all other fruit characteristics (including polyembryony) were similar to those of standard 'Gomera-1' (G-1) fruit. The progeny of this plant has, to date, proved to be morphologically identical to the mother plant. Studies of seedlings from normal G-1 trees growing in the same orchard showed that $10 \%$ of the plants had morphological characteristics similar to those of the putative polyploid seedling. Flow cytometry and chromosome count analyses confirmed that G-1 is diploid, whereas the putative polyploid is a stable tetraploid. The study also showed that the morphologically abnormal seedlings from diploid parent trees were spontaneous tetraploids.
\end{abstract}

The 'Gomera-1' (G-1) mango was originally described on the island of La Gomera in 1979 (Galán Saúco and García Samarín, 1979) as one of several polyembryonic mangoes commonly cultivated in the Canary Islands, and it has become the rootstock of choice in the Islands (Galán Saúco and Fernández Galván, 1987). It is probably the 'manga blanca' of Cuba, described by Popenoe in 1920 (Popenoe, 1976), where it still grows.

A G-1 seedling tree (G-1-P), with wider, more coriaceous leaves and wavier leaf margins than those of normal G-1, was found at the Instituto Canario de Investigaciones Agrarias (ICIA) in Valle Guerra (Tenerife). Further observations showed that its fruit are considerably larger than those of G-1, although all other fruit characteristics, including polyembryony, were similar. As these differentiating characteristics coincided with polyploidy expression in other species, a study was carried out to determine the possible polyploidy of this plant.

\section{Materials and Methods}

Morphological studies of 'Gomera-l'. Morphological characteristics of leaves,

Received for publication 3 Feb. 2000. Accepted for publication 21 July 2001. The cost of publishing this paper was defrayed in part by the payment of page charges. Under postal regulations, this paper therefore must be hereby marked advertisement solely to indicate this fact.

1'E-mail address: vgalan@icia.es. width, and degree of waviness of margins of mature leaves.

Survey of additional polyploid-like plants. A survey to locate other plants with morphology similar to that of G-1-P was conducted among the old local mango population in La Gomera, and in nurseries located in Tenerife and La Gomera.

Ploidy analysis. The following material was used for ploidy analysis: the 19 standard G-1 trees used in the progeny studies; the G-1-P plant; 30 seedlings of standard G-1, of which 15 had normal phenotypic characters and 15 exhibited characters similar to G-1-P; and three seedlings from G-1-P. Analysis was done by flow cytometry, and corroborated in some plants by chromosome counting.

The flow cytometry analyses were carried out using a ploidy analyzer (Partec, Münster, Germany) equipped with a mercury lamp (HBO $100 \mathrm{~W})$ and $\mathrm{kGl}$ and BG38 filters. Pieces of leaves $\approx 1 \mathrm{~cm}^{2}$ each were taken from a control diploid plant and from a suspected tetraploid plant, and finely chopped with a razor blade in $\approx 1 \mathrm{~mL}$ of a solution used for DNA extraction (Partec High Resolution DNA Kit, Type P, Solution A). After a gentle shaking, the sample was filtered through a $35-\mu \mathrm{m}$ mesh and $\approx 5 \mathrm{~mL}$ of 4',6-diamino-2-phenylindol staining was added (Partec High Resolution DNA Kit, Type P, Solution B). A minimum of 1000 nuclei were analyzed per sample. The histogram of fluorescence intensity obtained was analyzed with the DPAC v 2.0 program incorporated in the cytometer; for each analysis, this program determines the peak positions, the coefficient of variation, and the relative ploidy of the samples.

To corroborate the flow cytometry results, chromosome counts were also done of some plants from both morphologically different G-1 groups (i.e., standard and putative polyploids), using a modified Sass technique (Sass, 1958). Root tips 2 to $3 \mathrm{~mm}$ in length, excised from actively growing greenhouse plants, were treated for $16 \mathrm{~h}$ at $10{ }^{\circ} \mathrm{C}$ in an aqueous solution of $2 \mathrm{~mm} 8$ hydroxyquinoline. After fixing with a 1 glacial acetic acid : 3 absolute ethanol solution $(\mathrm{v} / \mathrm{v})$ for $3 \mathrm{~h}$, samples were hydrolyzed in $5 \mathrm{~N}$ $\mathrm{HCl}$ for $30 \mathrm{~min}$ at $30{ }^{\circ} \mathrm{C}$, treated with a solution of $0.2 \%$ ferric-ammonium sulfate for $2 \mathrm{~h}$, and stained with a $0.2 \%$ aqueous hematoxylin solution for $30 \mathrm{~min}$. A terminal portion $(\approx 1 \mathrm{~mm})$ of root tip was placed on a slide, one drop of a $45 \%$ acetic acid solution was added, and the specimen was covered with a cover slip and lightly squashed prior to counting using a microscope with an oil

immersion objective $(\times 1125)$. characteristics were recorded: color of young leaves; leaf color, texture (leathery), length,
Table 1. Quantitative parameters ${ }^{\mathrm{z}}$ of standard 'Gomera-1' mango vs. putative polyploid 'G-1-P' plant.

\begin{tabular}{lccccccc}
\hline \hline & \multicolumn{3}{c}{ Leaf parameters $(\mathrm{cm})$} & & \multicolumn{3}{c}{ Fruit parameters } \\
\cline { 2 - 4 } \cline { 7 - 8 } Samples & $\begin{array}{c}\text { Lamina } \\
\text { length }\end{array}$ & $\begin{array}{c}\text { Lamina } \\
\text { width }\end{array}$ & $\begin{array}{c}\text { Petiole } \\
\text { length }\end{array}$ & & $\begin{array}{c}\text { Wt } \\
(\mathrm{g})\end{array}$ & $\begin{array}{c}\text { Length } \\
(\mathrm{cm})\end{array}$ & $\begin{array}{c}\text { Width } \\
(\mathrm{cm})\end{array}$ \\
\hline Standard G-1 & $20.3 \pm 1.6 \mathrm{a}^{\mathrm{y}}$ & $5.6 \pm 0.5 \mathrm{a}$ & $3.1 \pm 0.7 \mathrm{a}$ & & $123.7 \pm 26.5 \mathrm{a}$ & $6.0 \pm 0.6 \mathrm{a}$ & $6.2 \pm 0.4 \mathrm{a}$ \\
G-1-P & $25.2 \pm 2.6 \mathrm{~b}$ & $8.3 \pm 0.9 \mathrm{~b}$ & $5.8 \pm 0.8 \mathrm{~b}$ & & $263.5 \pm 29.3 \mathrm{~b}$ & $7.9 \pm 0.3 \mathrm{~b}$ & $7.4 \pm 0.3 \mathrm{~b}$ \\
\hline
\end{tabular}

${ }^{2}$ The values represented are those of the mean $(n=10) \pm \mathrm{SD}$.

${ }^{y}$ Mean separation within columns by LSD, $P \leq 0.001$. 


\section{Results}

Morphological studies of 'Gomera-1'. The putative polyploid G-1-P had longer and wider leaves, with longer petioles, and fruit both larger and heavier than those of G-1 (Table $1)$, as well as darker mature-leaf color and wavier leaf margins (Fig. 1). Also observed (data not shown) were a coarser overall texture of the leaf, and inflorescences with denser pilosity and larger flowers.

Morphological studies of progeny. All the G-1-P seeds were polyembryonic and all subsequent seedlings exhibited the typical leaf morphology of the parent plant. Of the 441 bulk-sown seedlings from the $19 \mathrm{G}-1$ plants, $\approx 10 \%$ (46 plants) exhibited leaf characteristics similar to those of G-1-P.

Survey of additional polyploid-like plants. All the trees observed in La Gomera, both at nurseries and in orchards, exhibited standard 'Gomera-1' morphology.

Of the 4623 plants surveyed in Tenerife nurseries, $27(0.58 \%)$ had morphological characteristics similar to those of G-1-P. One Güimar nursery reported that several seedlings of this type, with poorly developed root systems, had appeared over the last few years and that its policy was to discard them.

Ploidy analysis. The putative polyploid G-1-P and its three progeny seedlings were found to be tetraploids. The $19 \mathrm{G}-1$ trees and the 15 progeny seedlings with normal morphology were diploids, whereas 14 of the 15 progeny seedlings that exhibited characters associated with putative polyploid plants were tetraploids. The ploidy level of plants from the two morphologically distinct groups was confirmed by classical chromosome counting. Graphs of flow cytometry analysis (Fig. 2) and chromosome counts (Fig. 3) for both $2 n$ and $4 n$ 'Gomera-1' are shown.

\section{Discussion}

Despite the long history of mango cultivation, the existence of tetraploids has not been satisfactorily confirmed. The only recorded case was that reported by Roi and Visweswariya in 1951 (as cited by Mukherjee, 1967), who stated that the polyembryonic cultivar Vellai-columban was tetraploid, although it was later found to be a diploid (Sharma et al., 1976). This latter finding could, however, be the result of studying different plants of the same cultivar, as occurred with the polyembryonic 'Gomera-1' of the present study.

After almost two centuries of culture of 'Gomera-1' in the Canaries, the present case is the only documented appearance of tetraploid mango plants. All other confirmed tetraploid plants (including those suspected to be tetraploid) appeared in nurseries in the area of the ICIA Experimental Station in Güimar. As the ICIA routinely provides seeds to neighboring nurseries, these seedlings presumably came from ICIA-supplied stock, particularly as no tetraploid-like plants were found in other nurseries.

Spontaneous tetraploids, apparently originating from single nucellar cells in the

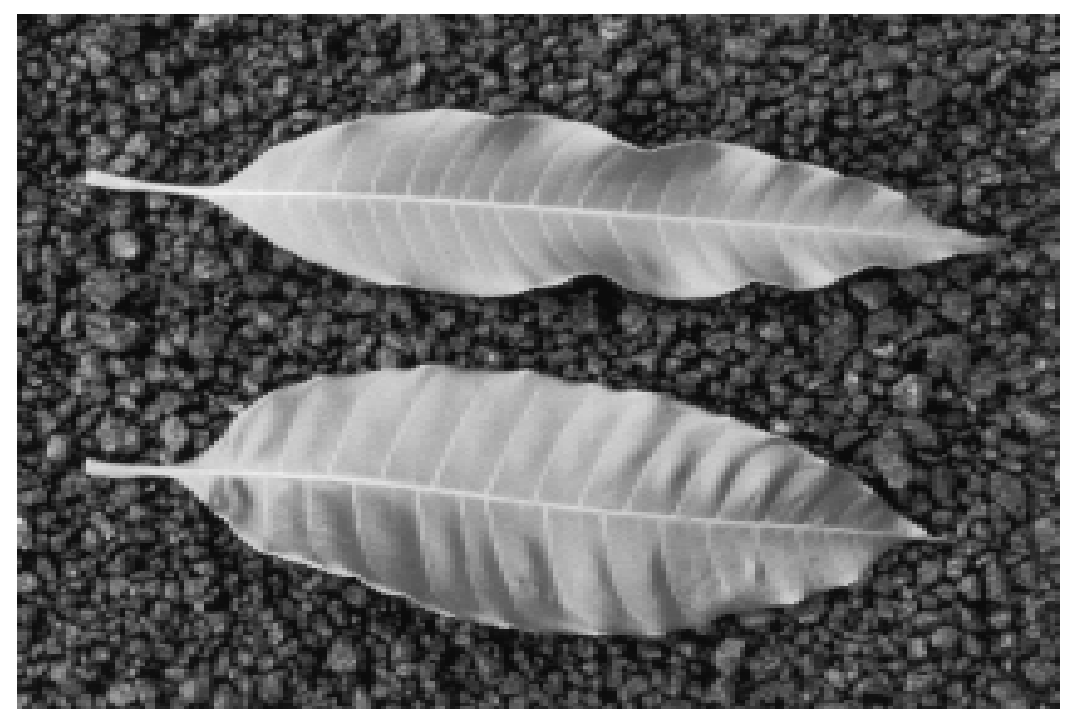

Fig. 1. Leaves of 'Gomera-1' (top) and putative polyploid G-1-P (bottom) mangoes.

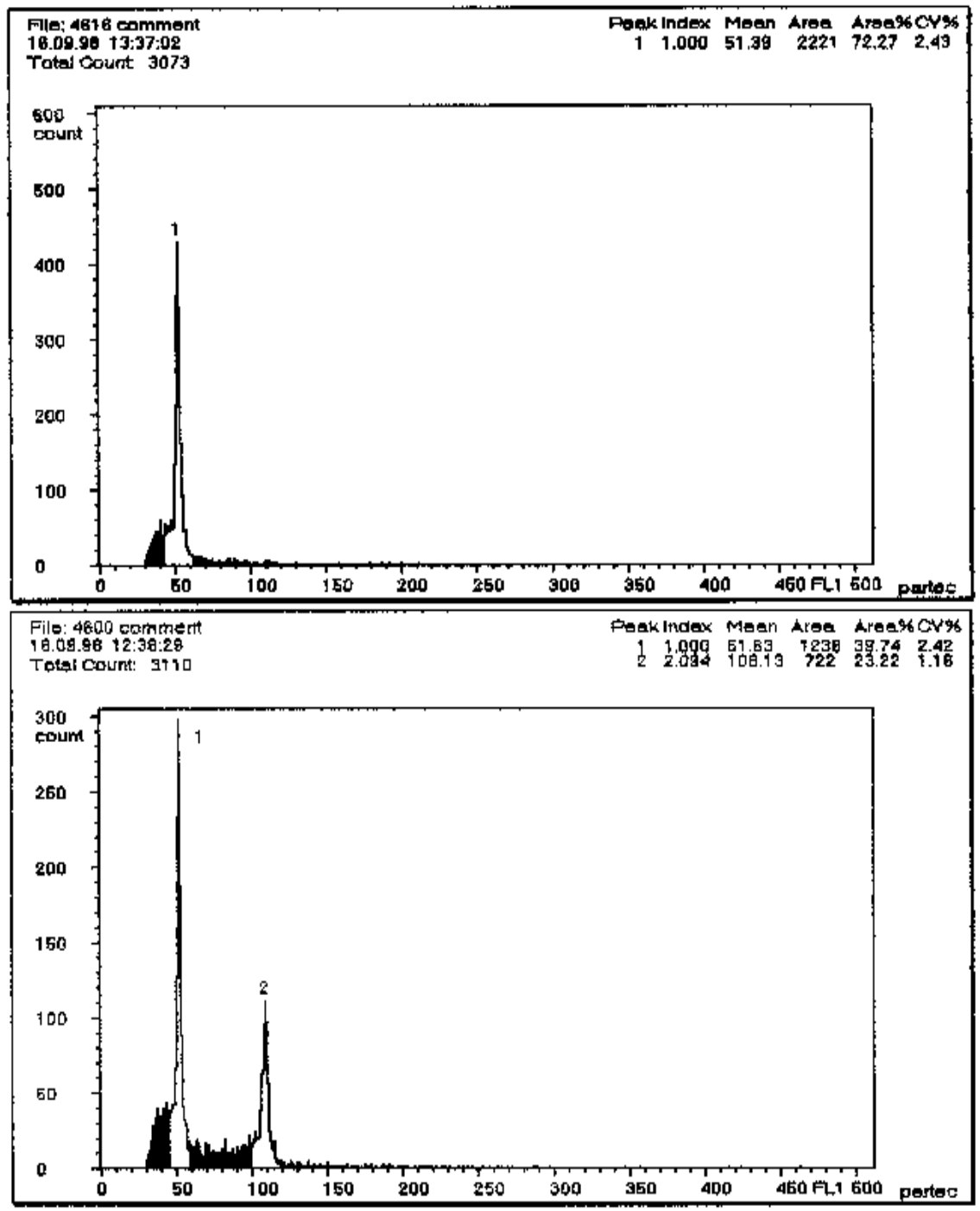

Fig. 2. DNA-histograms of DAPI-stained nuclear mango preparations. Peak 1, known diploid control plus analyzed diploid plant (peak index 1) (top). Peak 1, known diploid control; peak 2, analyzed tetraploid plant (peak index 1, diploid control; peak index 2.094, tetraploid plant (bottom). 


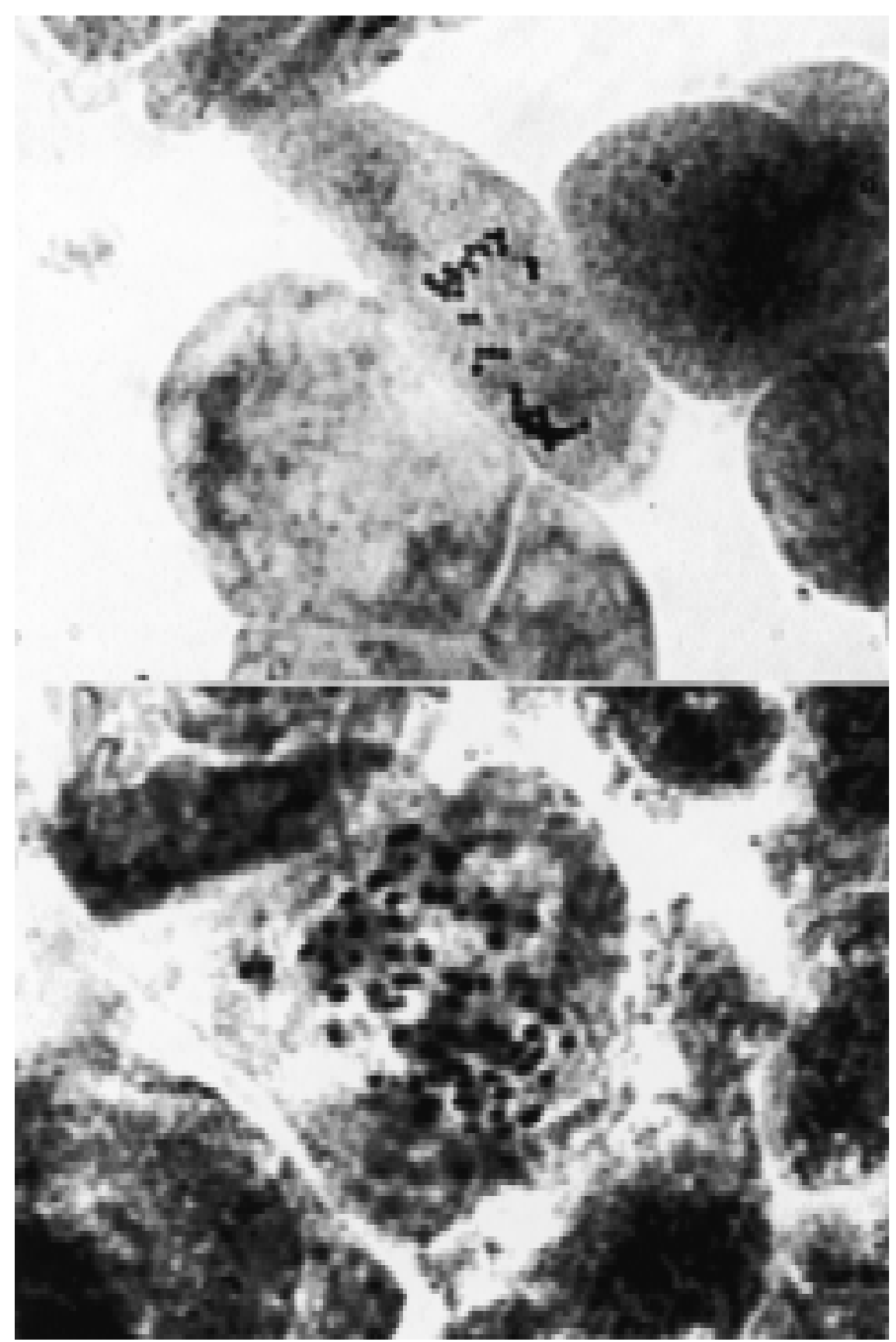

Fig. 3. Chromosome counts for $2 n$ (top) and $4 n$ (bottom) 'Gomera-1' mangoes.

ovule, also occur in other apomictic genera like Citrus (Barret and Hutchison, 1978; Cameron and Frost, 1968; Hutchison and Barret, 1981). Rates of spontaneous tetraploids in Citrus seem to be climate-related: in 'Troyer' citrange $[C$. sinensis (L.) Osb. $\mathrm{x}$
Formation of spontaneous tetraploids in nucellar mangoes may be influenced by climatic conditions, as is thought to occur in apomictic citrus trees. This may explain why no tetraploid-like plants were found in the mango-growing area of La Gomera (Valle Gran Rey, on the southern coast of the island), which is warmer than the Guiimar area of Tenerife. However, further investigation is required to determine the origin and factors that influence tetraploid formation in mangoes.

In the future, this tetraploid mango could be used to obtain triploids, as well as being a possible source of dwarf rootstocks, as is being done in Citrus (Lee, 1988).

\section{Literature Cited}

Barret, H.C. and D.J. Hutchison. 1978. Spontaneous tetraploidy in apomictic seedlings of Citrus. Econ. Bot. 32:27-45.

Cameron, J.A. and H.B. Frost. 1968. Genetics, breeding and nucellar embryony, p. 325-381. In: W. Reuther, H.J. Webber, and L.D. Batchelor (eds.). The citrus industry. Vol. 2. Div. Agr. Sci., Univ. of Calif., Berkeley.

Coello Torres, A., D. Fernández Galván, and V. Galán Saúco. 1997. Guía descriptiva de cultivares de mango. Monografías Técnicas. Consejería de Agricultura, Pesca y Alimentación, Gobierno de Canarias, Tenerife, Spain.

Galán Saúco, V. and D. Fernández Galván. 1987.El cultivo del mango en Canarias. Cuaderno Divulgación 1/87 CD. Consejería de Agr. y Pesca, Gobierno de Canarias, Tenerife, Spain.

Galán Saúco, V. and J. García Samarín. 1979. Pasado, presente y futuro del mango en Canarias. Cuaderno INIA 9. Min. Agr., Pesca y Alimentación, Madrid, Spain.

Hutchison, D.J. and H.C. Barret. 1981. Tetraploid frequency in nucellar seedlings from single trees of Carrizo and Troyer citrus hybrids. Proc. Intl. Soc. Citricult. 1:27-29.

Lee, L.S. 1988. Citrus polyploidy. Origins and potential for cultivar improvement. Austral. J. Agr. Res. 39:735-747.

Mukherjee, S.K. 1967. History, origin and botany, p. 1-13. In: C.G. Raghava Kurup, U. Warasinga Rao, P. Kachroo, and S.N. Tata (eds.). The mango: A handbook. Indian Council of Agr. Res., New Delhi.

Popenoe, W. 1976. Manual of tropical and subtropical fruits. Haffner Press, New York. (Facsimile 1920 ed.)

Sass, J.E. 1958. Botanical microtechnique. Iowa State Univ. Press, Ames.

Sharma, D.K., P.K. Majumder, and U.S. Kaicker. 1976. Chromosomal status of Vellai-columban (Mangifera indica L.). Current Sci. 45(18):675.

Union Internationale pour la Protection des Obtentions Végetales. 1987. Principes directeurs pour la conduite de l'examen des caracteres distintifs, de l'homogeneité et de la stabilité. Manguier. TG/112/3. Geneva. 